Volume 2 Nomor 2, Desember 2019

E-ISSN : 2655-7347

\title{
TANGGUNG JAWAB PT RAILINK TERHADAP KETERLAMBATAN PENUMPANG KERETA API BANDARA
}

\author{
Tasia Eda Lestari \\ (Mahasiswa Program S1 Fakultas Hukum Universitas Tarumanagara) \\ (E-mail: tasiaeda07@gmail.com)
}

\begin{abstract}
Amad Sudiro
(Dosen Fakultas Hukum Universitas Tarumanagara. Meraih Sarjana Hukum pada Fakultas Hukum Universitas Trisakti, Magister Manajemen pada Fakultas Manajemen STIE IPWI, Magister Hukum pada Fakultas Hukum Universitas Tarumanagara, Doktor (Dr.) pada Fakultas Hukum Universitas Indonesia.)

(E-mail: ahmads@fh.untar.ac.id)
\end{abstract}

\begin{abstract}
Transportation in Indonesia has experienced very rapid development, one of which is in land transportation, namely airport trains managed by PT Railink. But in the airport railroad operations there are also problems, namely delays. One of the incidents that occurred was the delay of the airport train with train number 7160 which caused passengers to miss flight schedules and could not fly that day. There is no law that discusses airport railroad, so the Act used still refers to the railroad regulations in general, namely Law 23 of 2007. So the author discusses how PT Railink's responsibility for the delay of airport train passengers. The author uses normative legal methods, interview data and survey results as supporting data. The government has issued a new regulation namely the Minister of Transportation's Regulation of the Republic of Indonesia Number PM 63 of 2019 concerning Minimum Service Standards for Transportation of People by Train, but in this regulation it has not been able to provide sufficient legal protection for passengers for airport train delays.
\end{abstract}

Keywords: airport railload, Indonesia, law 23 of 2007, Minister of Transportation's Regulation of the Republic of Indonesia PM 63 of 2019

\section{PENDAHULUAN}

\section{A. Latar Belakang}

Indonesia merupakan sebuah negara kepulauan yang terdiri dari 5 pulau besar yaitu Sumatera, Jawa, Kalimantan, Papua, Sulawesi. Pembangunan nasional diperlukan untuk menunjang kebutuhan-kebutuhan masyarakat di negara tersebut. Salah satu sarana yang menjadi sasaran pembangunan nasional adalah bidang ekonomi, 
Volume 2 Nomor 2, Desember 2019

E-ISSN : 2655-7347

karena perekonomian suatu negara memegang peranan penting dalam menunjang berhasilnya pembangunan di negara tersebut.

Sejalan dengan perkembangan perekonomian di Indonesia terutama mengenai barang dan jasa, maka diperlukan adanya sarana guna untuk menunjang mobilitas seseorang, barang dan jasa dari suatu tempat ke tempat lain yang berguna untuk kebutuhan masyarakat. Salah satunya sarana yang diperlukan adalah pengangkutan. Menurut Subekti perjanjian pengangkutan adalah suatu perjanjian, dimana satu pihak menyanggupi untuk dengan aman membawa orang atau barang dari satu tempat ke tempat lain sedangkan pihak yang lain menyanggupi akan membayar ongkosnya).

Sistem transportasi pada dasarnya dibagi menjadi 3 (tiga) jenis moda transportasi, yaitu moda transportasi udara, moda transportasi darat, dan transportasi laut. Masing-masing moda transportasi tersebut harus saling mendukung satu dengan lainnya agar terciptanya konektifitas yang baik sesuai dengan cita awal dibentuknya sistem transportasi. Moda transportasi darat merupakan moda transportasi yang paling mendasar dalam kehidupan manusia, mulai dari diciptakannya roda pertama di dunia hingga saat ini sudah diciptakannya kereta cepat memperlihatkan perkembangan yang sangat signifikan dalam pengembangan moda transportasi darat. Moda transportasi darat digemari karena moda transportasi ini sangat fleksibel serta mudah dijangkau oleh masyarakat, selain itu moda transportasi darat hanya membutuhkan biaya yang ringan dibandingkan dengan moda transportasi lainnya. Para pihak yang terkait dalam moda transportasi darat yaitu penumpang sebagai pengguna jasa dan pengangkut sebagai penyedia jasa. Salah satu bentuk dari moda transportasi darat adalah transportasi kereta api.

Pada awalnya kereta api di Indonesia muncul karena adanya rasa kesulitan sarana transportasi di Pulau Jawa ditinjau dari sudut pertahanan dan keamanan serta sudut ekonomi sejak awal abad ke-19. Pada masa itu kriminalitas dan keamanan dalam melakukan perjalanan jauh tidak aman, maka pada 15 Agustus 1840 Kolonel

\footnotetext{
1) Subekti, Hukum Perjanjian, (Jakarta: PT Intermasa, 1990), Cetakan VII, hlm. 1.
} 
Volume 2 Nomor 2, Desember 2019

E-ISSN : 2655-7347

Jhr.VanDerwijk mengusulkan agar pulau Jawa dibangun alat transpotasi baru yaitu Kereta Api, berdasarkan keberhasilan di Eropa yang telah mengatasi masalah yang serupa. ${ }^{2}$ Undang-Undang Nomor 23 Tahun 2007 Pasal 6 ayat (3) tentang Perkeretaapian menyaratkan agar adanya integrasi antara moda transportasi kereta api dengan moda transportasi lain.3 Salah satu bentuk integrasi tersebut adalah adanya kereta api bandara yang dioperasikan oleh PT. Railink. PT Railink, anak perusahaan dari PT Kereta Api Indonesia (Persero) dengan PT Angkasa Pura II (Persero) didirikan dengan visi untuk menyuguhkan semangat baru dalam pelayanan moda transportasi kereta api di Indonesia. PT Railink mempersembahkan sebuah layanan yang baru kali pertama hadir di Indonesia, yakni Kereta Api Bandara, bersamaan dengan pengoperasian perdana Bandara Internasional Kuala Namu pada tanggal 25 Juli 2013. Kereta Api Bandara pertama ini melayani penumpang dari kota Medan menuju Bandara Kuala Namu dan sebalikya. Setelah 3 tahun KA Bandara Kualanamu bertumbuh, PT Railink menghadirkan KA Bandara baru di Ibu Kota Negara yaitu KA Bandara Soekarno-Hatta (BSH) $\left.{ }^{4}\right)$

Pelaksanaan intergrasi antara kereta api dengan pesawat udara mengalami beberapa permasalahan, salah satunya adalah keterlambatan perjalanan kereta api bandara yang menyebabkan terlambatnya calon penumpang pesawat udara. Salah satu contoh kasus yaitu keterlambatan perjalanan akibat gangguan aliran listrik terjadi pada Kereta Api Bandara daerah operasional stasiun soedirman - stasiun soekarno hatta. Keterlambatan tersebut terjadi karena adanya gangguan aliran listrik.

Kronologi masalah terjadi sesaat setelah kereta api bandara berangkat dari Stasiun Soedirman pada pukul 18:15 WIB. Kereta api bandara tersebut berhenti di stasiun Batu Ceper pada pukul 19:26 WIB dan tidak dapat bergerak karena gangguan aliran listrik terjadi. Penumpang kereta api bandara tersebut dialihkan ke kereta api

\footnotetext{
2 Tim Telaga Bakti Nusantara, Sejarah Perkeretaapian Jilid 1, (Bandung: APKA,1997), hlm. 48

${ }^{3}$ Indonesia, Undang-Undang Nomor 23 Tahun 2007 Tentang Perkerataapian, Pasal 6 ayat (3)

${ }^{4}$ PT Railink, "https://www.railink.co.id/index.php/profile/id", diakses pada tanggal 5 April 2019 pukul 23.00
} 
Volume 2 Nomor 2, Desember 2019

E-ISSN : 2655-7347

selanjutnya pada pukul 20.06 WIB. Masalah tersebut tentunya menimbulkan kerugian materil dan immaterial bagi penumpang kereta api bandara, dua orang tercatat terganggu penerbangannya. ${ }^{5)}$ Berdasarkan latar belakang diatas, Penulis tertarik untuk membahas dan meneliti lebih lanjut yang dituangkan dalam jurnal dengan judul Tanggung Jawab PT Railink Terhadap Keterlambatan Penumpang Kereta Api Bandara

\section{B. Perumusan Masalah}

Berdasarkan latar belakang tersebut di atas, dapat dirumuskan permasalahan sebagai berikut. Bagaimana Tanggung Jawab PT Railink Terhadap Keterlambatan Penumpang Kereta Api Bandara Berdasarkan Undang-Undang Republik Indonesia Nomor 23 Tahun 2007 Tentang Perkeretaapian?

\section{Metode Penelitian}

Adapun metode penelitian yang digunakan dalam penulisan ini adalah :

1. Tipe Penelitian

Dalam melakukan penelitian ini, penulis menggunakan metode penelitian hukum normatif. Penelitian hukum normatif adalah suatu proses untuk menemukan suatu aturan hukum, prinsip-prinsip hukum maupun doktrin-doktrin hukum untuk menjawab permasalahan hukum yang dihadapi. ${ }^{6)}$

2. Jenis dan Sumber data

Dalam penelitian ini, penulis menggunakan jenis data sekunder. Data sekunder adalah data yang diperoleh dari hasil penelahaan kepustakaan

5 Tiara Sutari, "Kereta Bandara Mogok Operator Klaim Telah Periksa Armada, https://www.cnnindonesia.com/nasional/20180302133302-20-279952/kereta-bandara-mogokoperator-klaim-telah-periksa-armada, diakses pada tanggal 3 April 2018 pukul 22.00.

6) Mukti Fajar dan Yulianto Achmad, Dualisme Penelitian Hukum dan Empiris, Cetakan ke-1. (Yogyakarta: Pustaka Pelajar, 2010), hal. 34. 
Volume 2 Nomor 2, Desember 2019

E-ISSN : 2655-7347

atau penelahaan terhadap berbagai literatur atau bahan pustaka yang berkaitan dengan masalah atau materi penelitian yang sering disebut sebagai bahan hukum. ${ }^{7)}$

Berdasarkan data sekunder, maka bahan hukum dalam penelitian ini berupa:

a. Bahan hukum primer, yaitu meliputi peraturan perundang-undangan dan ketentuan yang berkaitan dengan penelitian ini yaitu Kitab UndangUndang Hukum Perdata, Undang-Undang Nomor 23 Tahun 2007 Tentang Perkeretaapian,

b. Bahan hukum sekunder, yaitu memberikan penjelasan mengenai hukum primer. Dalam hal ini bahan hukum sekunder yang digunakan penulis adalah buku dan literatur yang berhubungan dengan materi yang berkaitan.

c. Bahan hukum tersier, yaitu memberikan petunjuk terhadap bahan hukum primer dan sekunder. Dalam hal ini bahan hukum tersier penulis adalah Kamus Besar Bahasa Indonesia, Kamus Hukum dan Artikel Internet.

3. Teknik Pengumpulan Data

Teknik pengumpulan data yang digunakan yaitu studi kepustakaan. Studi kepustakaan dilakukan dibeberapa tempat, baik di pepustakaan Fakultas Hukum Universitas Tarumanagara, maupun mengakses data melalui internet dan wawancara.

4. Pendekatan Penelitian

Berkaitan dengan penelitian normatif, terdapat berbagai macam pendekatan. Pendekatan yang digunakan dalam penulisan hukum menurut Peter Mahmud Marzuki adalah sebagai berikut: ${ }^{8)}$

7) Ibid, hlm. 156.

8) Peter Mahmud, Penelitian Hukum, Cetakan ke-7. (Jakarta: Kencana Prenada Media Group, 2016). hlm. 93. 
Volume 2 Nomor 2, Desember 2019

E-ISSN : 2655-7347

a. Pendekatan kasus

b. Pendekatan perundang-undangan

c. Pendekatan historis

d. Pendekatan perbandingan

e. Pendekatan konseptual

Pendekatan yang penulis gunakan dalam penelitian hukum normatif ini adalah pendekatan perundang-undangan. Pendekatan perundangundangan adalah, penggunaan peraturan perundang-undangan sebagai dasar awal melakukan analisis. Pendekatan peraturan perundangundangan dilakukan karena peraturan perundang-undangan merupakan titik norma dari penelitian ini. Metode Pendekatan ini dianggap merupakan metode yang paling sesuai untuk menjawab permasalahan dalam penulisan ini, yang mengkaji mengenai tanggung jawab PT Railink terhadap keterlambatan penumpang kereta api bandara.

5. Teknik Analisis Data

Analisis data merupakan kegiatan dalam penelitian yang berupa melakukan kajian atau telaah terhadap hasil pengolahan data yang dibantu dengan teori-teori yang telah didapatkan sebelumnya.9) Teknik analisis data yang digunakan dalam penelitian ini adalah pendekatan kualitatif yaitu penelitian tentang riset yang bersifat deskriptif yang cenderung menggunakan analisis.

\section{PEMBAHASAN}

Tanggung Jawab PT Railink Terhadap Keterlambatan Penumpang Kereta Api Bandara Berdasarkan Undang-Undang Republik Indonesia Nomor 23 Tahun 2007 Tentang Perkeretaapian

\footnotetext{
${ }^{9)}$ Mukti Fajar ND dan Yulianto Achmad, Op. Cit., hlm. 182.
} 
Volume 2 Nomor 2, Desember 2019

E-ISSN : 2655-7347

Sistem perkeretaapian nasional saat ini sangat diharapkan untuk menjadi tulang punggung mobilitas nasional, hal ini terbukti dengan penambahan jalur-jalur kereta api baru, serta peningkatan-peningkatan fasilitas perkeretaapian yang ada di Indonesia. Tentu selain pembangunan yang berwujud fisik, pembentukan dan penyesuaian regulasi diperlukan guna menunjang operasional fasilitas yang dibangun.

Saat ini Undang-Undang Nomor 23 Tahun 2007 tentang Perkeretaapian (UU Perkeretaapian) menjadi regulasi penunjang bagi perkeretaapian nasional. Dibentuknya regulasi adalah semata-mata untuk melindungi para pihak dalam perkeretaapian mulai dari operator sampai dengan pengguna jasa. Hal ini diperlukan agar adanya kepastian hukum bagi para pihak sehingga melahirkan keadilan bagi para pemangku kepentingan (stakeholder).

Perkeretaapian menurut fungsinya dibagi menjadi 2 (dua) yakni perkeretaapian umum dan khusus, hal ini disebutkan dalam Pasal 5 ayat (1) UU Perkeretaapian. Selanjutnya pada ayat (2) pasal yang sama, pembagian dilakukan juga pada perkeretaapian umum dimana terdiri dari 2 (dua) jenis yakni perkeretaapian perkotaan dan antarkota. Sesuai dengan amanat dalam Pasal 6 UU Perkeretaapian, dalam ayat (3) dikatakan bahwa tatanan sistem perkeretaapian harus memiliki integrasi dengan moda transportasi lainnya. Hal ini menggambarkan bahwa perkeretaapian diharapkan menjadi connector antarmoda transportasi yang ada, keberadaan kereta api bandara merupakan salah satu bentuk dari perwujudan amanat Pasal 6 ayat (3) UU Perkeretaapian.

Dalam rangka mendukung mobilitas masyarakat yang berangkat menuju bandar udara atau menuju daerah perkotaan dari bandar udara, pemerintah membangun kereta api bandara. Pada awalnya kereta api bandara dibangun di Sumatera Utara, tepatnya di kota Medan, guna konektivitas dari Kota Medan menuju Bandara Udara Internasional Kualanamu, di Deli Serdang yang berlokasi kurang lebih 23 kilometer dari pusat kota Medan. Tentu untuk menunjang operasional bandara terbesar ketiga di Indonesia tersebut, diperlukan dukungan dari berbagai moda transportasi, salah satunya kereta 
Volume 2 Nomor 2, Desember 2019

E-ISSN : 2655-7347

api. Sebagai jawaban dari kebutuhan tersebut, pada tahun 2013 PT Railink ditunjuk sebagai operator dari kereta api bandara yang mana merupakan anak perusahaan dari PT Kereta Api Indonesia (Persero) dan PT Angkasa Pura II (Persero).

Selanjutnya pada tahun 2016, PT Railink menghadirkan layanan kereta api bandara di Bandara Udara Internasional Soekarno-Hatta setelah rampungnya pembangunan jalur kereta api antara Batu Ceper dengan Bandara Udara Internasional Soekarno-Hatta. PT. Railink di Jakarta saat ini melayani rute Manggarai menuju Bandara Udara Internasional Soekarno-Hatta melalui beberapa stasiun, yakni BNI City (Sudirman Baru), Duri, dan Batu Ceper. Sesuai penjabaran diatas, maka dapat disimpulkan bahwa kereta api bandara yang dioperasikan oleh PT. Railink merupakan bagian dari perkeretaapian umum perkotaan karena melayani perjalanan pulang-pergi (ulang-alik) dengan jangkauan melebihi wilayah administrasi kota pada sebuah wilayah perkotaan.

Namun, bukan tanpa masalah, operasional kereta api bandara Soekarno-Hatta pernah mengalami masalah yang cukup serius. Keterlambatan perjalanan kereta api terjadi pada tanggal 1 Maret 2018 di wilayah stasiun Batu Ceper. Pada pukul 19:25 Waktu Indonesia Barat (WIB), KA Bandara dengan nomor KA 7160 mengalami keterlambatan perjalanan akibat matinya pasokan listrik aliran atas (LAA). Akibat kejadian tersebut, 2 (dua) orang penumpang yang akan melanjutkan perjalanannya dengan pesawat udara terlambat dan akibatnya terpaksa dialihkan penerbangannya dengan penerbangan keesokan hari dan diberikan fasilitas penginapan. Tentu, hal ini merugikan pihak penumpang baik dari materi maupun immaterial.

Pada saat ini UU Perkeretaapian sendiri belum secara jelas mengatur mengenai tanggung jawab operator kereta api terhadap keterlambatan perjalanan kereta api atau pengaturan mengenai tata cara penanganan keterlambatan perjalanan kereta api (delay management). Hal ini bertolak belakang dengan tujuan serta cita-cita dari keberadaan kereta api, khususnya kereta api bandara. Dimana pada dasarnya keberadaan kereta api bandara diharapkan dapat membantu masyarakat untuk menuju dari/ke bandara dengan 
Volume 2 Nomor 2, Desember 2019

E-ISSN : 2655-7347

cepat dibandingkan dengan menggunakan angkutan lainnya. Perjalanan kereta api yang terstruktur dengan adanya grafik perjalanan kereta api (GAPEKA) menjadikan kereta api memiliki kepastian waktu keberangkatan dan kedatangan, sehingga meminimalisir kemungkinan terjadinya keterlambatan. Tidak seperti moda transportasi darat lain yang memiliki potensi keterlambatan lebih tinggi sehingga tidak dapat memberikan kepastian waktu akibat faktor-faktor abstrak yang dapat terjadi seperti kemacetan.

Tanggung jawab operator kereta api terhadap keterlambatan perjalanan kereta api diatur dalam Pasal 133 ayat (2) UU Perkeretaapian, dimana disebutkan bahwa operator kereta api wajib memberikan informasi atas penundaan keberangkatan atau keterlambatan kedatangan kereta api kepada pengguna jasa (penumpangan) dengan alasan yang jelas. Hal ini lebih lanjut diatur dalam Peraturan Pemerintah Nomor 72 Tahun 2009 tentang Lalu Lintas dan Angkutan Kereta Api (PP Nomor 72 Tahun 2009) yang sebagaimana diubah menggunakan Peraturan Pemerintah Nomor 61 Tahun 2016 tentang Perubahan Atas Peraturan Pemerintah Nomor 72 Tahun 2009 Tentang Lalu Lintas dan Angkutan Kereta Api (PP Nomor 61 Tahun 2016). Pada pasal 85 PP Nomor 72 Tahun 2009 disebutkan bahwa perjalanan kereta api harus sesuai dengan apa yang diatur oleh Gapeka dan apabila terjadi keterlambatan yang melebihi batas toleransi waktu operasi, penyelenggara prasarana dapat mengambil langkah untuk mengurangi perjalanan kereta api, hal terkait keterlambatan kereta api diatur lebih lanjut dalam peraturan Menteri.

Pada saat kejadian berlangsung, penanganan keterlambatan kereta api dilakukan berdasarkan Peraturan Menteri Perhubungan Republik Indonesia Nomor PM. 48 Tahun 2015 tentang Standar Pelayanan Minimum Angkutan Orang Dengan Kereta Api (Permenhub Nomor 48 Tahun 2015). Didalam Permenhub tersebut, belum ada pengaturan khusus mengenai standar pelayanan terhadap penumpang kereta api bandara. Pada Pasal 5 Permenhub Nomor 48 Tahun 2015 disebutkan bahwa, dalam hal keterlambatan kereta api perkotaan, operator kereta api hanya perlu memberikan formulir informasi keterlambatan apabila dimintakan oleh penumpang jika 
Volume 2 Nomor 2, Desember 2019

E-ISSN : 2655-7347

keterlambatan 30 (tiga puluh) menit atau lebih dan mendapatkan kompensasi pembatalan transaksi perjalanan untuk keterlambatan lebih dari 2 (dua) jam.

Penulis berpendapat, kompensasi yang diberikan belumlah cukup untuk mengakomodasi kebutuhan dari kereta api bandara, mengingat formulir yang dimaksud hanya sebuah tanda bukti yang menyatakan adanya keterlambatan perjalanan kereta api. Untuk kompensasi pembatalan transaksi perjalanan (penumpang mendapatkan kembali uang yang telah dibayarkannya) menurut penulis juga tidak menyelesaikan masalah utama dalam kejadian ini. Mengingat tujuan dari penumpang untuk menggunakan jasa angkutan kereta api bandara yang paling utama adalah untuk dapat mencapai bandara tepat pada waktunya sebelum terlambat dalam melakukan pelaporan penerbangan (check-in), sehingga aturan ini akan sangat merugikan penumpang, karena penggantian harga tiket, tidaklah sebanding dengan kerugian yang dialami penumpang, mulai dari kerugian waktu, sampai dengan kerugian atas harga tiket pesawat yang telah dibayarkan oleh penumpang.

Setelah dilakukan pencarian data lebih lanjut dengan melakukan wawancara dengan pihak operator kereta api bandara yakni PT. Railink yang mana dalam hal ini diwakili oleh Bapak Muchtar sebagai VP Corporate Secretary dan Legal. Menurut informasi yang beliau berikan, saat ini PT. Railink selaku operator (penyedia sarana) kereta api menyewa kepada PT. Kereta Api Indonesia dalam perihal prasarana pendukung operasi. Pada saat kejadian tersebut, PT. Railink bertanggung jawab dengan memberikan penginapan serta tiket pesawat penerbangan keesokan harinya. Setelah kejadian yang bersangkutan, PT. Railink menerapkan kebijakan baru, yakni dengan menghimbau penumpang untuk menggunakan kereta api bandara dengan jarak waktu 3 (tiga) jam antara waktu kedatangan kereta bandara di Bandara Soekarno-Hatta dengan waktu keberangkatan pesawat. Apabila penumpang mengalami keterlambatan penerbangan akibat menggunakan perjalanan kereta dibawah jarak waktu yang ditentukan, PT. Railink tidak bertanggung jawab atas kerugian dari keterlambatan penumpang dalam mengejar waktu penerbangan. 
Volume 2 Nomor 2, Desember 2019

E-ISSN : 2655-7347

Penulis berpendapat kebijakan baru yang di keluarkan oleh PT Railink merupakan hal yang tidak tepat. Berdasarkan hasil wawancara dengan Ibu Siti Nurbaiti, tidak seharusnya pengangkut membuat kebijakan baru yang dapat menutup tannggung jawabnya jika terjadi keterlambatan dan membebankan tanggung jawab tersebut kepada penumpang. Ketentuan dalam UU Perkeretaapian pasal 132 menyebutkan sebagai berikut:

\section{Pasal 132}

a. Penyelenggara sarana perkeretaapian wajib mengankut orang yang telah memiliki karcis

b. Orang yang telah memiliki karcis berhak memperoleh pelayanan sesuai dengan tingkat pelayanan yang telah dipilih.

c. Karcis sebagaimana dimaksud pada ayat (1) merupakan tanda bukti terjadinya pengangkutan orang.

Maka, sebagai penyelenggara sarana kereta api bandara, PT Railink wajib mengangkut penumpang dan mengantarkan penumpang berdasarkan pelayanan yang telah dipilihnya. Jika penumpang telah memilih menggunakan kereta api bandara dengan waktu yang di tentukannya, tidak seharusnya PT Railink membuat kebijakan baru mengenai jarak waktu tersebut untuk menutup tanggung jawabnya jika terjadi keterlambatan. Hal ini tentu sangat bertolak belakang dengan tujuan dan cita-cita dibentuknya kereta api, khususnya kereta api bandara. Dimana pada dasarnya keberadaan kereta api bandara diharapkan dapat membantu masyarakat untuk menuju dari/ke bandara dengan cepat dibandingkan dengan menggunakan angkutan lainnya. Jika penumpang telah memilih berangkat pada waktu yang ditentukannya, selama KA Bandara memberikan pelayanan sesuai dengan apa yang diperjanjikan, namun penumpang tetap terlambat, maka hal ini merupakan kesalahan penumpang. Namun jika penumpang mengalami keterlambatan yang diakibatkan karena kesalahan KA Bandara, hal ini menjadi kesalahan dari KA Bandara sebagai pihak pengangkut. 
Volume 2 Nomor 2, Desember 2019

E-ISSN : 2655-7347

Syarat batal yang ditentukan baik didalam tiket maupun peraturan perundangundangan menurut penulis sangat merugikan bagi penumpang, mengenai syarat batal, KUH Perdata mengaturnya dalam pasal 1265 sampai dengan 1267, yakni sebagai berikut.

\section{Pasal 1265}

"Suatu syarat batal adalah syarat yang bila dipenuhi akan menghapuskan perikatan dan membawa segala sesuatu kembali pada keadaan semula, seolah-olah tidak pernah ada suatu perikatan. Syarat ini tidak menunda pemenuhan perikatan; ia hanya mewajibkan kreditur mengembalikan apa yang telah diterimanya, bila peristiwa yang dimaksud terjadi"

\section{Pasal 1266}

"syarat batal dianggap selalu dicantumkan dalam persetujuan timbal balik, andai kata salah satu pihak tidak memenuhi kewajibannya. Dalam hal demikian persetujuan tidak batal demi hukum, tetapi pembatalan harus dimintakan kepada pengadilan. Permintaan ini juga harus dilakukan, meskipun syarat batal mengenai tidak dipenuhinya kewajiban dinyatakan di dalam persetujuan. Jika syarat batal tidak dinyatakan dalam persetujuan, maka hakim dengan melihat keadaan, atas permintaan tergugat, leluasa memberikan suatu jangka waktu untuk memenuhi kewajiban, tetapi jangka waktu itu tidak boleh lebih dan satu bulan.”

\section{Pasal 1267}

"pihak yang terhadapnya perikatan tidak memenuhi, dapat memilih; memaksa pihak lain untuk memenuhi persetujuan, jika hal itu masih dapat dilakukan, atau menuntut pembatalan persetujuan, dengan penggantian biaya, kerugian dan bunga."

Syarat batal dapat menghapuskan sebuah perikatan dan mengembalikan segala sesuatu seperti sebelum adanya perikatan. Namun, kreditur (dalam hal ini adalah pengangkut) hanya perlu mengembalikan apa yang telah diterima olehnya bila terjadi suatu peristiwa (dalam hal ini keterlambatan perjalanan kereta api bandara). Ketentuan syarat batal dalam tiket perjalanan kereta api bandara ini tentu sangat merugikan dan 
Volume 2 Nomor 2, Desember 2019

E-ISSN : 2655-7347

tidak tepat digunakan dalam sebuah perjanjian transportasi, karena perjanjian dalam pengangkutan berbentuk perjanjian baku, dimana penumpang tidak ada andil sama sekali pada saat waktu perjanjian dibentuk. Menjadi merugikan adalah karena dalam Pasal 1265 kreditur hanya diwajibkan untuk mengembalikan apa yang telah diterimanya. Karena, kerugian yang diderita penumpang kereta api bandara adalah terlambat dalam mengejar waktu keberangkatan pesawat udara, sehingga ada kerugian yang lebih besar dibandingkan dengan harga tiket.

Berdasarkan hasil wawancara dengan PT Railink terkait kebijakan baru serta wawancara dengan ahli transportasi darat dan wawancara dengan Direktoral Jendral Perkeretaapian mengenai revisi Permenhub Nomor PM 48 Tahun 2015 tentang standar pelayanan minimum angkutan orang dengan kereta api, yang akan membahas mengenai kereta api bandara sudah disahkan pada tanggal 14 Oktober 2019 dan diberlakukan pada tanggal 17 Oktober 2019, yaitu menjadi Peraturan Menteri Perhubungan Republik Indonesia Nomor PM 63 Tahun 2019 Tentang Standar Pelayanan Minimum Angkutan Orang Dengan Kereta Api (Permenhub Nomor PM 63 Tahun 2019), dan mecabut Permenhub Nomor PM 48 Tahun 2015.

Dalam Permenhub Nomor PM 63 Tahun 2019, telah diatur secara khusus mengenai kereta api bandara sebagaimana hasil wawancara dengan PT Railink, Direktoral Jendral Perkeretaapian dan ahli transportasi darat, yang menjelaskan mengenai kebijakan baru tersebut yakni dengan menghimbau penumpang untuk menggunakan kereta api bandara dengan jarak waktu 3 (tiga) jam antara waktu kedatangan kereta bandara di Bandara Soekarno-Hatta dengan waktu keberangkatan pesawat. Pasal 9 Permenhub Nomor PM 63 Tahun 2019 menyebutkan sebagai berikut:

\section{Pasal 9}

a. Dalam hal terjadi keterlambatan keberangkatan perjalanan terjadwal Kereta Api Bandara lebih dari 15 (lima belas) menit pada stasiun Kereta Api keberangkatan, berhak melakukan pembatalan perjalanan dan mendapatkan kompensasi berupa pergantian kerugian senilai harga karcis. 
Volume 2 Nomor 2, Desember 2019

E-ISSN : 2655-7347

b. Dalam hal terjadi keterlambatan perjalanan Kereta Api Bandara:

1) Penyelenggara sarana perkeretaapian harus menyediakan alternatif moda lain menuju stasiun tujuan yang biayanya ditanggung oleh penyelenggara sarana Perkeretaapian; atau

2) Penumpang dapat membatalkan karcis dan mendapat pengembalian seluruh biaya karcis

c. Kompensasi sebagaimana dimaksud pada ayat (1) tidak berlaku dalam hal penyelenggara sarana Perkeretaapian telah memberitahukan akan terjadinya keterlambatan dan penwumpang tetap memilih menggunakan jasa Kereta Api tujuan ke bandara.

d. Kompensasi sebagaimana dimaksud pada ayat (2) tidak berlaku apabila penumpang berangkat dengan waktu kedatangan di stasiun bandara kurang dari waktu 2 jam dari waktu keberangkatan pesawat

Penerapan kebijakan pemberian kompensasi berupa pengembalian harga tiket adalah tidak tepat, jika terjadi keterlambatan perjalanan kereta api bandara yang diinginkan oleh calon penumpang pesawat terbang yang mana pada saat itu sedang menjadi penumpang kereta api bandara, bukanlah kompensasi pengembalian seharga karcis tersebut, karena kerugian yang diterima penumpang bila terjadi keterlambatan KA Bandara yaitu tertinggal jadwal pesawat udara. Hal ini jelas bertentangan dengan amanat dalam UU Perkeretaapian Pasal 6 ayat (3) dikatakan bahwa tatanan sistem perkeretaapian harus memiliki integrasi dengan moda transportasi lainnya. Hal ini menjelaskan bahwa perkeretaapian diharapkan menjadi connector antarmoda transportasi yang ada agar lahir sebuah intergrasi antarmoda angkutan darat dengan angkutan udara, sehingga membantu masyarakat untuk menuju dari/ke bandara dengan cepat dibandingkan dengan menggunakan angkutan darat lainnya. Penulis berpendapat, selain integrasi dengan tujuan mendukung perpindahan orang atau barang, integrasi dalam regulasi mengenai tanggung jawab masing-masing operator 
Volume 2 Nomor 2, Desember 2019

E-ISSN : 2655-7347

pengangkut antarmoda juga harus diterapkan agar adanya perlindungan hukum bagi para penumpang atau pengirim barang.

Mengenai ketentuan penumpang berangkat dengan waktu kedatangan di stasiun bandara kurang dari 2 (dua) jam dari waktu keberangkatan pesawatnya, penulis tidak setuju dengan ketentuan tersebut, berdasarkan hasil wawancara dengan Ibu Siti Nurbaiti, tidak seharusnya negara membuat peraturan baru yang dapat menutup tannggung jawab pihak pengangkut jika terjadi keterlambatan dan membebankan tanggung jawab tersebut kepada penumpang, karena penumpang memiliki hak untuk menentukan kapan waktu keberangkatannya dan memiliki hal untuk mendapatkan pelayanan sesuai yang dipilihnya sesuani dengan ketentuan dalam UU Perkeretaapian pasal 132 ayat (2).

Seiring berjalannya waktu, perubahan hukum tentu perlu untuk menyesuaikan aturan yang ada dengan perkembangan jaman yang sangat pesat ini, termasuk dalam hukum transportasi khususnya dalam bidang perkeretaapian. Perubahan tersebut. Kebutuhan atas hukum terjadi karena perlunya perlindungan bagi setiap orang atas kepentingannya, dalam hal ini yaitu penumpang KA Bandara. Teori perlindungan hukum menurut Satjipto Raharjo10) yang menyatakan bahwa

"Hukum melindungi kepentingan seseorang dengan cara mengalokasi suatu kekuasaan kepadanya untuk bertindak dalam rangka kepentingannya tersebut. Pengalokasian kekuasaan ini dilakukan secara terukur, dalam arti ditentukan keluasan dan kedalamannya."

Berdasarkan teori tersebut penulis berpendapat bahwa harus dijelaskan secara jelas hak-hak dari penumpang kereta api bandara dalam sebuat peraturan perundangundangan secara tertulis demi terciptanya kepastian hukum. Dalam hal menciptakan

${ }^{10}$ Satjipto Raharjo, Permasalahan Hukum di Indonesia, (Bandung: Alumni, 1983), hal.53 
Volume 2 Nomor 2, Desember 2019

E-ISSN : 2655-7347

kepastian hukum, diperlukan suatu penegakkan hukum. Gustav Radburch mengatakan bahwa $^{11):}$

"Kepastian hukum adalah suatu jaminan bahwa suatu hukum harus dijalankan dengan cara baik. Kepastian adalah tujuan utama dari hukum, sehingga jika hukum tidak memiliki kepastian, maka tujuan dari hukum tersebut tidak terwujud."

Berdasarkan pendapat dari Gustav Radburch, dapat ditarik kesimpulan bahwa kepastian hukum harus berjalan sesuai dengan ketentuan yang ada, dan untuk dapat berjalan sesuai dengan ketentuan yang ada maka penegakkan hukumnya juga harus berjalan secara baik.

Pada saat ini, Indonesia belum memiliki peraturan perundang-undangan yang membahas mengenai kereta api bandara secara rinci mengenai hal kompensasi jika terjadi keterlambatan oleh kereta api bandara, walau sudah dibentuk peraturan yang baru yaitu Permenhub Nomor PM 63 Tahun 2019, Permenhub tersebut tidak juga membahas mengenai perlindungan bagi pihak penumpang kereta api bandara jika terjadi keterlambatan yang mengakibatkan ketinggalan pesawat udara secara rinci dan jelas.

Disisi lain, dalam peraturan tersebut, terlihat bahwa pihak pengangkut seperti dilindungi oleh peraturan tersebut dari kemungkinan penggantian kerugian akibat keterlambatan karena ada pengaturan yang membahas mengenai ketentuan penumpang diharuskan berangkat dengan waktu kedatangan di stasiun bandara kurang dari 2 (dua) jam dari waktu keberangkatan pesawatnya, jika tidak maka kompensasi tersebut tidak berlaku bagi penumpang. Sehingga, menurut penulis Permenhub Nomor PM 63 Tahun 2019, yang baru disusun guna mengisi kekosongan hukum dalam hal pengaturan mengenai kereta api bandara belum dapat memberikan perlindungan hukum yang cukup bagi pihak penumpang atas keterlambatan kereta api bandara, disisi lain,

${ }^{11}$ Sulardi dan Yohana Puspitasari Wardoyo, Kepastian Hukum, Kemanfaatan, Dan Keadilan Terhadap Perkara Pidana Anak, Jurnal Yudisial Vol.8 No. 3 Desember, (Malang: Fakultas Hukum Universitas Muhammadiyah Malang, 2015). 
Volume 2 Nomor 2, Desember 2019

E-ISSN : 2655-7347

Permenhub Nomor PM 63 Tahun 2019 justru hanya memberikan perlindungan hukum bagi pihak pengangkut agar tidak memberikan ganti kerugian akibat keterlambatan karena adanya peraturan tersebut.

Dalam penyelenggaraan sarana perkeretaapian, sebagaimana tertulis pada UU Perkeretaapian Pasal 132 ayat (3), karcis merupakan suatu bukti terjadinya perjanjian angkutan orang. Berdasarkan Pasal 1313 KUH Perdata, "Suatu Perjanjian adalah suatu perbuatan dimana satu orang mengikatkan diri terhadap suatu orang lain atau lebih". Jika dilihat dari arti perjanjian pada pasal tersebut, maka perjanjian terjadi jika ada suatu perbuatan nyata, tidak hanya dalam bentuk fikiran yang abstrak. Dalam suatu perjanjian khususnya perjanjian pengangkutan perkeretaapian, tentu ada perjanjian yang terpenuhi dan tidak terpenuhi. Jika suatu perjanjian tidak terpenuhi, atau jika suatu prestasi tidak terpenuhi, maka disebut sebagai suatu wanprestasi. Wanprestasi dikategorikan menurut Subekti, yaitu ${ }^{12)}$ :

a. Tidak melakukan apa yang disanggupinya atau dilakukannya.

b. Melaksanakan apa yang diperjanjikannya, tetapi tidak sebagaimana yang diperjanjikan.

c. Melakukan apa yang diperjanjikan, tetapi terlambat.

d. Melakukan suatu perbuatan yang menurut perjanjian tidak dapat dilakukan.

Jadi jika dilihat dari unsur-unsur tersebut, maka PT Railink sebagai penyelenggara sarana kereta api bandara, yang melaksanakan apa yang diperjanjikan tapi tidak sebagaimana mestinya atau melaksanakan namun terlambat dari waktu yang ditentukan, dapat dikatakan sebagai wanprestasi atau cedera janji. Penumpang yang mendapatkan kerugian, memiliki hak untuk mendapatkan ganti kerugian yang timbul berdasarkan KUHPer pasal 1243,

Pasal 1243

"Penggantian biaya, kerugian dan bunga karena tidak dipenuhinya suatu perikatan mulai diwajibkan, bila debitur, walaupun telah dinyatakan lalai, tetapi lalai

${ }^{12)}$ R.Subekti, Hukum perjanjian,Jakarta 1979 cetakan ke-II, halaman 50 
Volume 2 Nomor 2, Desember 2019

E-ISSN : 2655-7347

untuk memenuhi perikatan itu, atau jika sesuatu yang harus diberikan atau dilakukannya hanya dapat diberikan atau dilakukannya dalam waktu yang melampaui waktu yang telah ditentukan."

Berdasarkan ketentuan dari pasal ini, penumpang sebagai pihak yang merasa dirugikan akibat terjadinya keterlambatan KA Bandara dapat meminta ganti kerugian kepada pihak yang melakukan wanprestasi yaitu PT Railink selaku penyelenggara sarana KA Bandara. Ganti kerugiannya bisa meliputi biaya nyata yang telah dikeluarkan, kerugian yang timbul sebagai akibat terjadinya wanprestasi tersebut, dan bunga. Kerugian yang timbul akibat terjadinya wanprestasi tersebut, yaitu penumpang mengalami ketinggalan pesawat udara akibat keterlambatan KA Bandara, karena hal itu penumpang dapat meminta kompensasi atas ketinggalan pesawat udara tersebut.

\section{PENUTUP}

\section{A. Kesimpulan}

Berdasarkan data hasil penelitian serta analisis yang telah dilakukan, maka penulis dapat memberikan kesimpulan, pada saat itu karena belum ada aturan yang mengatur mengenai kereta api bandara, maka tanggung jawab PT Railink terhadap keterlambatan penumpang kereta api bandara mengikuti aturan kereta api umum yaitu UU Perkeretaapian Nomor 23 Tahun 2007 dan Permenhub Nomor PM 48 Tahun 2015 tentang standard pelayanan minimum angkutan orang dengan kereta api. Dalam peraturan tersebut belum secara jelas mengatur mengenai tanggung jawab operator kereta api terhadap keterlambatan perjalanan kereta api atau pengaturan mengenai tata cara penanganan keterlambatan perjalanan kereta api.

Pada dasarnya keberadaan kereta api bandara diharapkan dapat membantu masyarakat untuk menuju dari/ke bandara dengan cepat dibandingkan dengan menggunakan angkutan lainnya. Meskipun pada saat itu sudah ada itikad baik dari pihak penyelenggara sarana kereta api bandara yaitu PT Railink dengan memberikan ganti kerugian kepada penumpang yang tertinggal jadwal penerbangannya dengan 
Volume 2 Nomor 2, Desember 2019

E-ISSN : 2655-7347

pengalihan penerbangan keesokan harinya dan memberikan fasilitas penginapan, tentu hal ini tetap merugikan pihak penumpang baik dari materi maupun immaterial.

Dalam peraturan baru yang dikeluarkan pemerintah saat ini yaitu Permenhub Nomor PM 63 Tahun 2019 tentang Standar Pelayanan Minimum Angkutan Orang Dengan Kereta api, sudah diatur mengenai kereta api bandara tetapi belum dapat memberikan perlindungan hukum yang cukup bagi pihak penumpang atas keterlambatan kereta api bandara, justru memberikan perlindungan hukum bagi pihak pengangkut agar tidak memberikan ganti kerugian akibat keterlambatan karena adanya peraturan baru tersebut, dengan memberikan syarat mengenai ketentuan penumpang diharuskan berangkat dengan waktu kedatangan di stasiun bandara kurang dari 2 (dua) jam dari waktu keberangkatan pesawatnya, jika tidak maka kompensasi tersebut tidak berlaku bagi penumpang.

\section{B. Saran}

Penulis terhadap hasil penelitian yang telah dilakukan memberikan saran sebagai berikut:

1. Bagi Pemerintah, harus dibentuknya Peraturan Perundang-undangan mengenai kereta api bandara yang mengatur integrasi mengenai tanggung jawab masing-masing operator pengangkut antarmoda, dan dalam hal kompensasi mengenai perlindungan bagi pihak penumpang kereta api bandara jika terjadi keterlambatan yang mengakibatkan ketinggalan pesawat udara tanpa membuat syarat mengenai ketentuan penumpang diharuskan berangkat dengan waktu kedatangan di stasiun bandara kurang dari 2 (dua) jam dari waktu keberangkatan, karena tujuan penumpang memilih kereta bandara karena efisiensi waktu.. Hal ini ditujukan agar adanya kepastian hukum dan memberikan perlindungan hukum bagi para penumpang kereta api bandara saat terjadi wanprestasi. 
Volume 2 Nomor 2, Desember 2019

E-ISSN : 2655-7347

2. Bagi PT Railink, diharapkan PT Railink menambah sarana dan prasarana baru dengan kondisi yang baik untuk beroperasi, memberikan pelatihan mengenai pengoperasian kereta dengan sistem digital kepada setiap masinis kereta api bandara.

3. Bagi Penumpang, dengan teknologi informasi saat ini yang sangat maju, penumpang dapat mencari informasi mengenai hak-haknya, dan penumpang harus lebih peduli terhadap hak-haknya yang harus dilindungi.

4. Bagi akademisi, diharapkan dapat lebih lanjut membahas hukum mengenai kereta api khususnya mengenai kereta api bandara, karena belum ada literaturnya.

\section{DAFTAR PUSTAKA}

\section{A. Buku}

Fajar, Mukti dan Yulianto Achmad. Dualisme Penelitian Hukum dan Empiris. Yogyakarta: Pustaka Pelajar, 2010.

Mahmud, Peter. Penelitian Hukum. Jakarta: Kencara Prenada Media Group, 2016

Raharjo, Satjipto. Permasalahan Hukum di Indonesia. Bandung: Alumni, 1983

Subekti. Hukum Perjanjian. Jakarta: PT Intermasa, 1990

Subekti. Hukum perjanjian. Cetakan ke-II. Jakarta: PT Intermasa, 1979

Tim Telaga Bakti. Sejarah Perkeretaapian Jilid 1. Bandung: APKA, 1997

\section{B. Peraturan Perundang-Undangan}

Indonesia, Undang-Undang Nomor 23 Tahun 2007 Tentang Perkerataapian. . Pengaturan yang dibuat oleh Presiden Republik Indonesia Nomor 72 Tahun 2009 tentang Lalu Lintas dan Angkutan Kereta Api.

. Pengaturan yang dibuat oleh Menteri Perhubungan Republik Indonesia Nomor PM. 48 Tahun 2015 tentang Standar Pelayanan Minimum Angkutan Orang Dengan Kereta Api. 
Volume 2 Nomor 2, Desember 2019

E-ISSN : 2655-7347

Pengaaturan yang dibuat oleh Menteri Perhubungan Republik Indonesia Nomor 63 Tahun 2019 Tentang Standar Pelayanan Minimum Angkutan Orang Dengan Kereta Api.

\section{Artikel}

PT Railink. "Profil PT Railink". https://www.railink.co.id/index.php/profile/id.

Sutari, Tiara. "Kereta Bandara Mogok Operator Klaim Telah Periksa Armada, https://www.cnnindonesia.com/nasional/20180302133302-20-

279952/kereta-bandara-mogok-operator-klaim-telah-periksa-armada. 